\title{
CONTENTION OVER CONTAGION Citizen Responses to COVID-19 Policies
}

\section{Danielle Resnick}

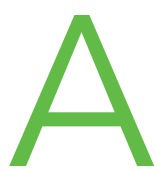

$t$ the outset of 2021, COVID-19 continues to test the limits of state-society relationships in much of the developing world. On January 7, Senegal's capital Dakar experienced violent demonstrations opposing a nighttime curfew imposed by the government under a new state of emergency law intended to limit the spread of the coronavirus (Ollivier 2021). A week later, Tunisia implemented a new national lockdown, sparking successive nights of rioting in various cities across the country that prompted intervention by the army. In both cases, grievances over the economic impacts of movement restrictions motivated protesters (Cordall 2021).

Citizens' perceptions about the equity and acceptability of policy actions to reduce coronavirus contagion have been critical to ensuring voluntary compliance with such decisions. IFPRI's COVID-19 Policy Response Portal (CPR) complemented its tracking of government policy actions throughout 2020 with an inventory of citizen responses to such actions (IFPRI 2020). This project note reviews key temporal and regional trends in citizen mobilization, as well as major categories of grievances.

\section{MODALITIES OF MOBILIZATION}

IFPRI's CPR has focused on four main types of citizen actions. The first includes protests and riots, some of which were symbolic, largely peaceful demonstrations against government decision-making and some of which involved more active attacks against police and military officials enforcing COVID-19 restrictions or against other citizens. A second category includes strikes by healthcare workers over the lack of sufficient personal protective equipment (PPE), long working hours, and insufficient pay. A third set of actions captured by the CPR targeted violence against the health community, including destruction of infrastructure (for example, testing and quarantine centers) and aggression against healthcare workers. Such actions often were prompted by communities who were misinformed about how the coronavirus spreads and believed proximity to nurses, doctors, and health facilities increased the likelihood of catching the virus, or who felt that patients and family members were not being treated with appropriate care by the medical community (see Vento et al. 2020). In addition, the CPR captured incidents of noncompliance with government mandates reported in local media outlets, including failure to wear masks or maintain social distancing.

Collectively, the CPR recorded more than 5,000 instances of these various citizen actions during 2020 across the 33 countries in the database. Protests and riots were by far the main form of citizen action, constituting 88 percent of the recorded events. Health worker strikes account for 8.6 percent of total activities while noncompliance with government policies made up 1.9 percent and violent treatment of the healthcare community made up 1.2 percent of the total cases. As seen in Figure 1, many of these actions, especially protests and riots, peaked during the initial wave of COVID-19 restrictions in April and saw a smaller resurgence in September.

\section{PROTEST ACTIVITIES AND THE ROLE OF INTERMEDIARIES}

As seen in Figure 2, the four countries with the most protests and riots were India (2,751), Pakistan (362), Tunisia (323), and Bangladesh (263). The large number of protest activities in India can be attributed to the combined effects of multiple, concurrent factors, including the very abrupt announcement of the country's lockdowns in March, rising fuel prices beginning in mid-2020 that angered those in the transport sector, and attempted reforms to the agriculture 


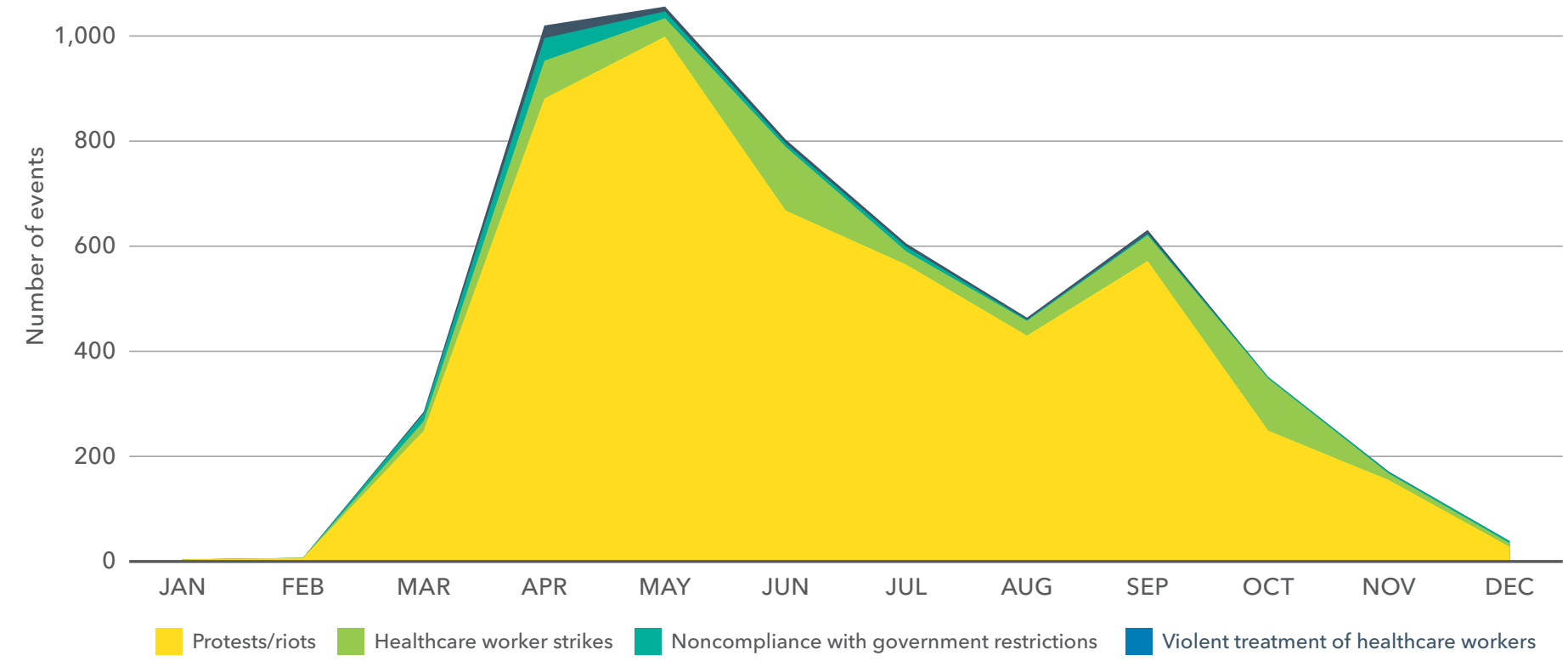

Source: Calculated from IFPRI's COVID-19 Policy Response Portal (2020).

market procurement system that were stimulated by the pandemic (Gettleman, Singh, and Kumar 2020). Notably, in South Asia, opposition and leftist political parties played a more notable role in organizing and joining protests, particularly when coronavirus policies affected the cost of living, than in other regions captured in the CPR.

However, countries such as Tunisia, Honduras, and Armenia experienced riot activity that, in relation to the size of their populations, far exceeded others. Tunisia has very active trade unions, which had played an important role in the Arab Uprisings of 2011 (Feltrin 2019). During the pandemic, many of the Tunisian protests have been organized under the Tunisia General Labor Union or its affiliates. Honduras had among the longest and most stringent lockdown policies, for the period from March 2020 up through January 2021 (Hale et al. 2020). Absolute lockdowns were accompanied by the provision of basic needs based on national identification numbers (see IFPRI 2020). Despite these lockdowns, COVID-19 cases have continued to climb, and reports of government corruption related to coronavirus funds have increased citizen frustrations (Garrison 2020).

Some scholarship on contentious politics suggests that protests are more likely where the environment is more open and liberalized because the costs of collective action are lower, that is, the police and military are less likely to arrest or violently deter protesters (Tarrow 1998). However, others suggest that protests are more likely in closed systems with few participatory and inclusionary mechanisms, where citizens have few opportunities to influence policymakers through conventional means (Brockett 1991). From the CPR country sample, protests against government policies were less likely in places with extreme restrictions on civil liberties, such as China, Ethiopia, Myanmar, and Rwanda, and more prevalent in countries such as Tunisia and India, with greater civil liberties (Freedom House 2020). However, democratic Ghana and Malawi did not experience a comparatively higher number of protests, and some places with more restrictive civil liberties, such as Bangladesh, Honduras, Pakistan, and Uganda, did see greater citizen mobilization. This suggests that the political environment is not a sufficient determinant of protest activity, and that factors such as the intensity of lockdowns, perceived government capacity, and the role of intermediaries-for example, political parties and unions-were equally relevant factors.

Figure 3 disaggregates protests and riots according to the main source of protesters' grievances or by the main category of demonstrators. One-third of protests are directly related to grievances around lockdown measures. In particular, citizens were angered by the inability to travel, requirements to quarantine, the imposition of curfews, and police enforcement of social distancing and mask requirements. The second-most important category was 


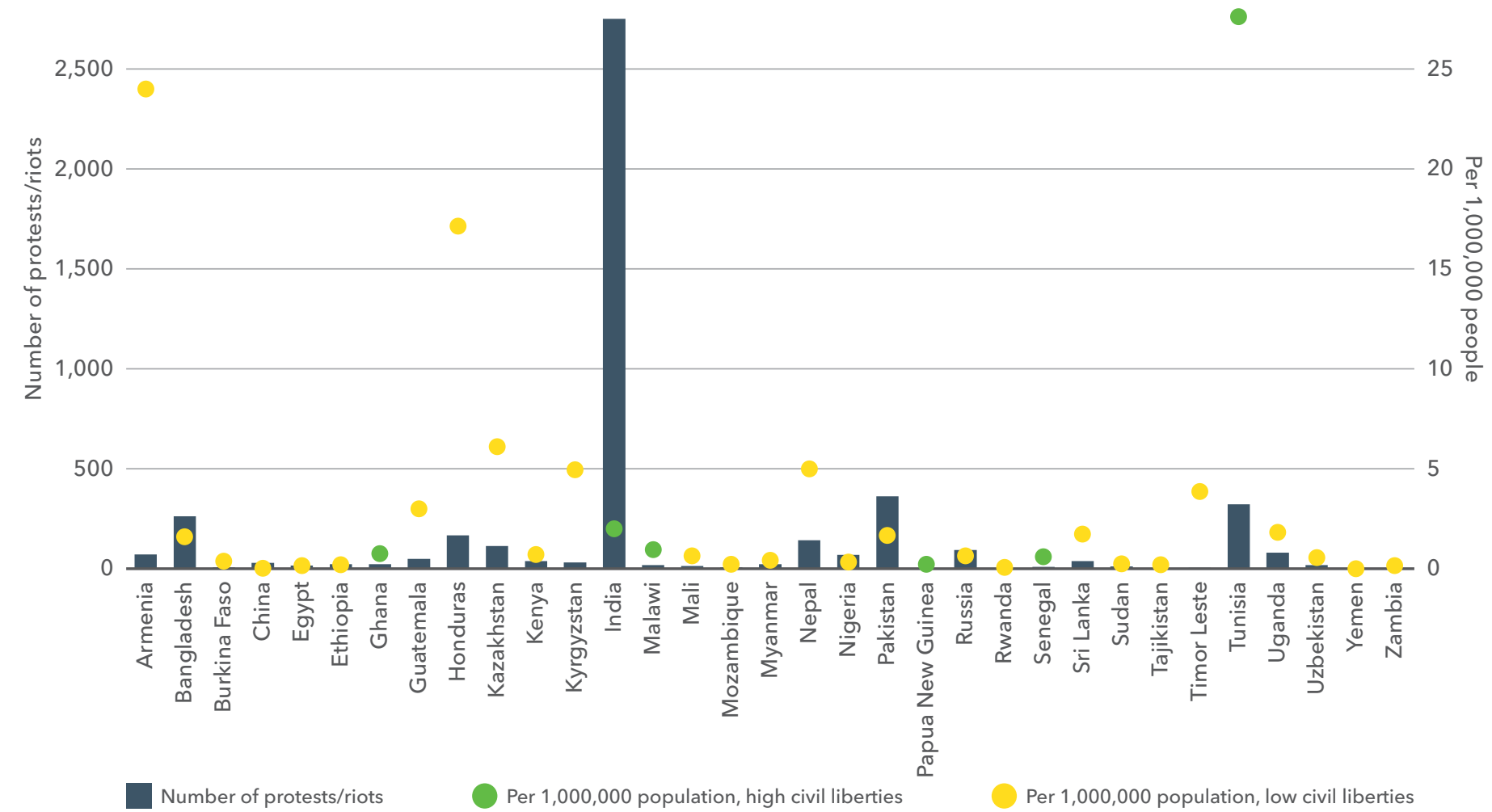

Source: IFPRI's COVID-19 Policy Response Portal (2020).

Notes: Yellow dots indicate that the country scores below 34 out of 60 on Freedom House's 2020 index, which is the threshold below which countries are deemed "not free" or "partly free." Green dots indicate the country scores higher on the index.

\section{FIGURE 3 Distribution of protest activities by source of grievances or category of demonstrators}

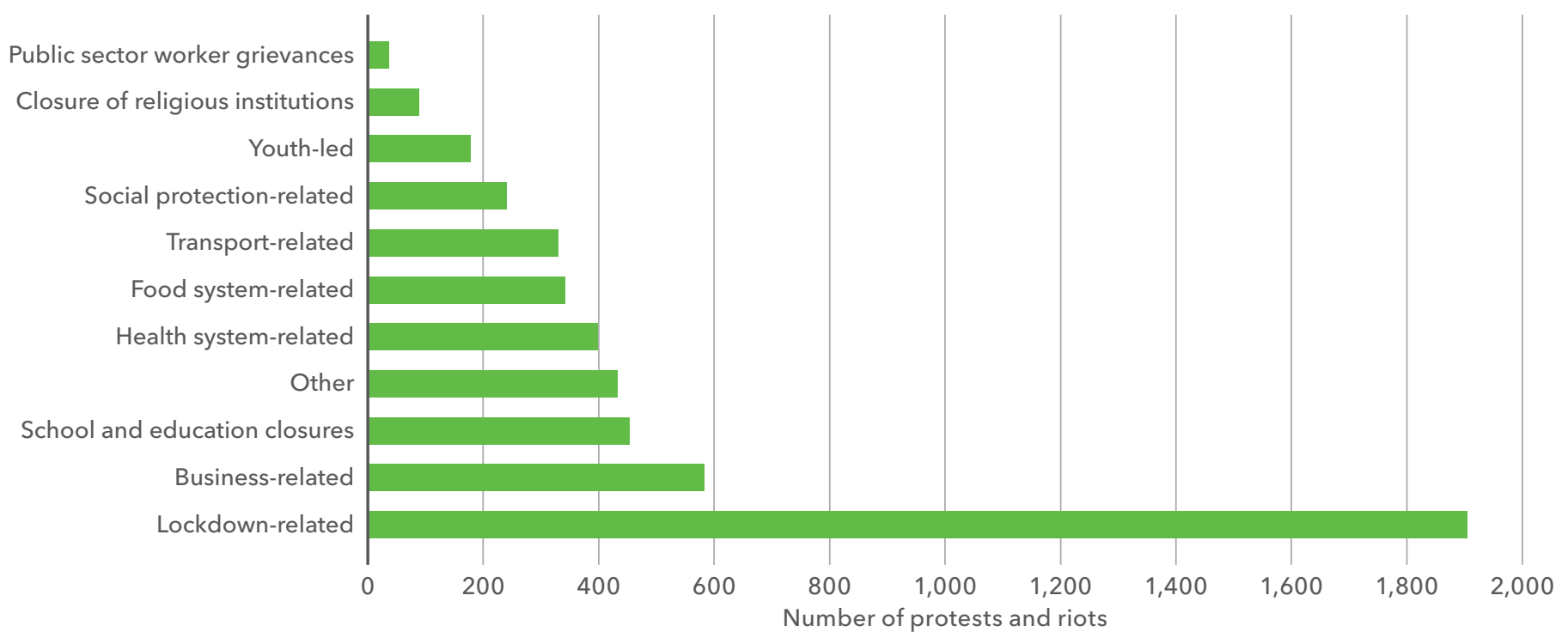

Source: IFPRI's COVID-19 Policy Response Portal (2020). 
business-related protests and riots. These included factory employees, store owners, miners, hotel companies, travel agents, and other categories of workers mobilizing against the economic repercussions of reduced hours and business closures. There were 342 cases of protests categorized as being related to the food system. These were protests that involved farmers, food hawkers and traders, and employees in food-related processing.

A number of farmer protests were organized by farmers' unions, such as the Bharatiya Kisan Union (BKU) and All India Kisan Sabha (AIKS) in India, and by other civil society organizations, including the Women Democratic Front in Pakistan, which organized protests in multiple cities of Sindh province in mid-May. By contrast, most protests by informal food traders appear to have been organically organized and often sparked by closures of markets or removal of some traders to assist with social distancing, or by fees and charges still being levied on their trading stalls despite closures.

\section{CONCLUSIONS}

Government reactions to COVID-19 in many countries have tested the strength of the "social contract," that is, the implicit agreement that governs the designation of rights and the provision of resources between states and citizens (Hickey and King 2016). The multiplicity of policy actions needed to manage the many uncertainties of this health crisis inevitably have led to some citizen dissatisfaction. Protests, strikes, violence, and actions of noncompliance have all been employed to show either discontent with policy actions or concern about policy inaction. For the countries included in the CPR, protests have been the primary form of mobilization, and most have been linked directly to lockdown-related decisions. Some protests have escalated into violence and confounded efforts to contain the spread of the virus. This suggests that going forward, governments will not only face the challenge of rebuilding their economies and health systems but some will also need to regain trust and reestablish legitimacy in the eyes of their populations.

\section{REFERENCES}

Brockett, C. 1991. "The Structure of Political Opportunities and Peasant Mobilization in Central America." Comparative Politics 23 (3): 253-274.

Cordall, S. 2021. "'People Are Hungry': Why Tunisia's Youth Are Taking to the Streets," Guardian, January 20. https://www.theguardian.com/global-development/2021/ jan/20/people-are-hungry-why-tunisias-youth-are-taking-to-the-streets

Feltrin, L. 2019. "Labour and Democracy in the Maghreb: The Moroccan and Tunisian Trade Unions in the 2011 Arab Uprisings." Economic and Industrial Democracy 40 (1): 42-64.

Freedom House. 2020. Freedom in the World 2020: A Leaderless Struggle for Democracy. New York.

Garrison, K. 2020. "Lack of Planning in Honduras Covid-19 Purchases Risks Millions in Public Funds." Transparency International. https://www.transparency.org/en/blog/ lack-of-planning-in-honduras-covid-19-purchases-risks-millions-in-public-funds\#

Gettleman, J., K. D. Singh, and H. Kumar. 2020. "Angry Farmers Choke India's Capital in Giant Demonstrations." New York Times, November 30.

Hale, T., S. Webster, A. Petherick, T. Phillips, and B. Kira. 2020. Oxford COVID-19 Government Response Tracker. Blavatnik School of Government. https://www.bsg.ox.ac.uk/research/research-projects/oxford-covid-19-governmentresponse-tracker

Hickey, S., and S. King. 2016. "Understanding Social Accountability: Politics, Power and Building New Social Contracts." Journal of Development Studies 52 (8): 1225-1240. http://dx.doi.org/10.1080/00220388.2015.1134778

International Food Policy Research Institute (IFPRI). 2020. Covid-19 Policy Response Portal. Available at: https://www.ifpri.org/project/ covid-19-policy-response-cpr-portal

Ollivier, T. 2021. "Tensions à Dakar en raison du retour du couvre-feu." Radio France Internationale. https://www.rfi.fr/fr/afrique/20210107-tensions-\%C3\%A0-dakaren-raison-du-retour-du-couvre-feu

Tarrow, S. 1998. Power in Movement: Social Movements and Contentious Politics. Cambridge: Cambridge University Press.

Vento, S., F. Cainelli, and A. Vallone. 2020. "Violence Against Healthcare Workers: A Worldwide Phenomenon with Serious Consequences." Frontiers in Public Health 8: $1-4$.

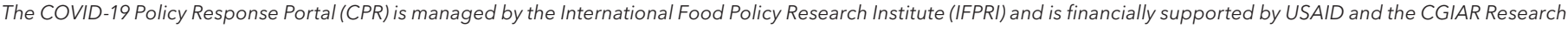
Program on Policies, Institutions, and Markets (PIM). This publication has been prepared as an output of the CPR. Contributing partners to the CPR include Michigan State University's Food Security Group, Global Alliance for Improved Nutrition (GAIN), Indaba Agricultural Research Institute (IAPRI) of Zambia, Tegemeo Institute of Agricultural Policy and Development of Kenya, the Center of Studies for Peace and Development (CEPAD) of East Timor, and the Institute for Integrated Development Studies (IIDS) of Nepal. This publication has not been independently peer reviewed. Any opinions expressed here belong to the author(s) and are not necessarily representative of or endorsed by IFPRI.

\section{INTERNATIONAL FOOD POLICY RESEARCH INSTITUTE}

A world free of hunger and malnutrition

\section{IFPRI is a CGIAR Research Center}

